\title{
Using Blockchain in WAQF, Wills and Inheritance Solutions in the Islamic System
}

\author{
Submitted 15/03/21, $1^{\text {st }}$ revision 12/04/21, $2^{\text {nd }}$ revision 30/04/21, accepted 25/05/21
}

\begin{abstract}
Walaa J. Alharthi ${ }^{1}$
Abstract:

Purpose: The paper aims to provide a review of literature on the Islamic social institution of $W A Q F$, dissecting the components of WAQF and the classic Islamic laws that guide its formation and implementation. WAQFs are Islamic social finance institutions that have played a critical role in achieving sustainable development in Islamic society. During the Ottoman era, it was operated effectively to ensure the founder's wishes until the advent of Islamic finance. The study highlights the challenges that the WAQF institution faces and the viability of the Blockchain system in mitigating these challenges and managing WAQF across the globe, which should help achieve the convectional objectives WAQF.

Approach/Methodology/Design: The study reviewed the most recent research papers on the WAQF Islamic social finance institution to isolate the institution's components, legal framework and challenges, and outline the solutions Blockchain system can provide.

Findings: The study shows that the main challenge obstructing the rejuvenation of the WAQF system to its lost glory has been lack of data, compromised historical records in the event of the Founders' demise, lack of transparency, and inappropriate auditing. Through smart contracts on Blockchain, there is a surety of efficacy and effective performance of WAQF institution and the realization of the founders' objectives.

Practical Implications: The study will contribute positively to understanding the historical importance of WAQF as an Islamic social institution and a predecessor to Islamic finance for academia and the possibility of utilizing Blockchain systems in managing WAQF transactions across the globe.

Originality/Value: This study believes in contributing to the Blockchain system's understanding as a possible solution to the challenges facing the Islamic social finance system.
\end{abstract}

Keywords: Blockchain, smart contract, secure payment, Islamic banking system, WAQF.

JEL classification: $G 0, F 3$.

Paper type: Research study.

${ }^{1}$ College of Community/Computer science and Information, Taibah University, Madinah, Saudi Arabia, Wharthi@taibahu.edu.sa 


\section{Introduction}

WAQFs are Islamic social institutions that have played a critical role in achieving sustainable development in Islamic society (Abbasi, 2012). During the Ottoman era, it was operated effectively to ensure the founder's wishes until recently when Islamic finance arrived. Islamic social finance organizations such as WAQF have faced severe challenges in improving governance structure to ensure strict adherence to the Shariah laws and achieve long-term economic efficiency (Laallam et al., 2020).

Blockchain has created a new system for recording and managing business transactions with a limited need for intermediaries (Abojeb and Habib, 2019). With the increasing dominance in the global market, the system is expected to provide a high level of governance that is cost-effective compared to other payment methods and traditional technologies (Pilkington, 2016; Noja et al., 2021). Some scholars have argued that the alternative systems to the fiat money systems such as Blockchain will enhance competition with banks since cryptocurrency does not require physical bank accounts and auditing (Swan, 2015). At the same time, others argue that the Blockchain system will open the door for tax evasion and auditing, creating a longterm effect on the government budget and the overall reduction in the GDP. Besides the debate by scholars and opinion leaders, there have been continuous and deliberate efforts to introduce this technology in different Islamic finance sectors, particularly Islamic social finance.

This research paper gives insight into the use of Blockchain as an alternative in WAQF, Wills, and Inheritance solutions in the Islamic system and how the innovative technology can be used to build up an electronic system.

\section{Classical Islamic Law of WAQF, Wills and Inheritance}

Within the first three centuries, after Islam was introduced, Muslim scholars created a legal institution known as WAQF to act as a charitable trust. Two types of WAQF were created, WAQFKHAIRI and WAQFAHLI or DHURRIE. The WAQFKHAIRI was created for an endowment for a religious or public-like object, while WAQFAHLI focused on the family endowment. In either case, the objective, or the purpose of WAQF was to please God (Abbasi, 2012). This ultimately devolved into a charitable cause until precondition was introduced (Abbasi, 2012). The WAQF was commonly used in endowing mosques, hospitals, and other charitable organizations, and complex laws were created to control the creation and administration of the trusts. As part of the Islamic laws, regulations were created to name the endowed property owner, the material of endowment, and the beneficiary. The "Hanafi School of law" states that through the act of endowment, the founder surrenders all property rights and changes it to Haqq Allah.

Through the WAQF, property owners were able to separate the property title from the revenues' entitlement. As part of the family endowment or will, Muslims could access greater control over those who receive the property's benefits (Alidin et al., 
2018). Earlier, such endowments could lead to conflicts and litigations, mainly because they continued in perpetuity. WAQF in pre-modern Muslim societies revealed many family issues at the time, and within its context, there were stricter laws on how much the testator may leave to some individuals and the heirs that could take a compulsory share of the inheritance. Like other religious affiliations, Muslims had a strong desire to control their property after death (Hassan et al., 2018). The amount of property one wishes to give as part of the WAQF is determined by personality, perceived merit, and other factors. However, there are other inheritance rules within the Islamic law that hinders the testator from giving away their property as per their wish (Alzubaidi and Abdullah, 2017). These rules allowed only up to onethird of the wealth to be given through a specific bequest with specific limits of who receives such. The rest of the wealth can be divided according to complex formulas, which the testator has no absolute power to change.

During the pre-modern Muslim era, Muslims were inventing devices to avoid the rigid inheritance rules, and the jurists were cooperative in allowing these activities. Since lifetime transfers were not subjected to numerous rules, they were assimilated to be part of the "estate planning" during the pre-modern society (Salarzehi et al., 2010). The most evident type of transfer used for this purpose was the WAQFAHLI, or family endowment. Even though not outlined in the Quran, the WAQF dates from the first few centuries. According to the "Maliki school of law", WAQF can be established as a will or created inter vivos (Abbasi, 2012). In the case of vivos, it takes effect immediately and cannot be revoked. If created as a will, it should adhere to the traditional inheritance law (Rashid, 2018). There was also a lifetime WAQF which was not exposed to any form of size restrictions. The founder had to identify the first generation then create rules for passing the property through other coming generations.

The concept of WAQF helped Muslims achieve the religious obligations of providing for their families while at the same time creating diverse practical objectives. Through the family endowment, founders could keep properties from being divided to ensure it remains in the family (Hassan et al., 2018). There is literature that suggests that transfers were meant to deny women some opportunities, but that was not the case. Even though women were secondary beneficiaries, they were often included in the deeds and their male counterparts. It provided an opportunity for founders to offer inheritance for both male and female children equally, which was contrary to the conventional Islamic inheritance rules, which stated that the son's share in the inheritance package should be twice that of the daughter (Abbasi, 2012).

In the Islamic religion, the concept of WAQF is debated based on the prevailing spirit of altruism which is an integral part of the Islam way of life. Muslims perceive charity as a means of transfer of wealth from the affluent to the less fortunate and a way of self-development. Simultaneously, the transmission of wealth is considered a way of achieving Allah's pleasure and reward in the afterlife (Karim, 2010). There are three fundamental principles of Islamic laws that defined Waqf as a charitable trust. It must be irretrievable, perpetual, and Incontrovertible. In addition to these principles, the 
ultimate purpose of WAQF should be religious. The system has a remarkable resilience, and many have endured more than a millennium. Historical sources reveal Waqf of Ayyubids in Syria and Palestine, which dates to the beginning of the 12th century.

\section{Components of WAQF}

\subsection{Founder}

Since WAQF is a contract, the founder, also known as al-wāqif, must initiate the process and enter a contract. According to Islamic law, the founder must be an adult, be of sound mind, and financially capable of engaging in a WAQF. Even though this is an Islamic project, being an Islam is not a requirement. If the founder is critically sick, the Waqf is subjected to similar regulations as the will (Zheng et al., 2018).

\subsection{Funding Declaration}

This is a written document that forms part of the WAQF and is supplemented with a verbal affirmation. Regardless of the type of declaration, the jurist holds that it is binding and irreversible until it is ultimately delivered to the final beneficiary or used (Pilkington et al., 2016). Once used, however, WAQF changes to institutional property.

\subsection{Estate}

This is also called a'aqarat or al-muhabbas and must be objects of a contract. These objects should be legal within the realms of Islamic law. Simultaneously, the objects should be original in the public domain (Al-Razouki, 2018). This means that an existing public property cannot be used as a WAQF. The property should not have been previously pledged to someone. Traditionally, the estate pledged to WAQF was immovable, but many movable and intangible goods were considered. This includes gold and silver. This raised the debate on the jurisdiction around cryptocurrencies in line with Islamic laws.

\subsection{Beneficiaries}

Beneficiaries are another component of WAQF and can either be a person or public projects such as hospitals, mosques, or charitable organizations. Earlier, the founder could specify the beneficiaries of a WAQF. In many cases, when there is no specificity, public entities like mosques, bridges, or water wells are the heirs of WAQF in Muslim nations (Rabbani et al., 2020). In the current legislation, WAQFs dictates clarity as either for "charitable cause" or "family" where the beneficiaries are the relatives. The founder can also state that half of the property goes to the family while the other goes to public projects. To qualify as a beneficiary in a WAQF, there are conditions which, must be met: 
- The beneficiary should be identified.

- They should not have differences with the Muslims.

- The heir should not use the Waqf in a manner that contradicts the principles and policies of the Muslim community.

There has been a continuous debate among jurists on whether the founder can reserve exclusive rights once a property is given as a WAQF. For many scholars, once it is created, it cannot be taken back. This means the founder loses rights over the property.

\subsection{Administration}

Since there is a range of beneficiaries, the founders appoint the administrator to monitor the implementation of rules set under the WAQF. There is an option for the founder to be the administrator of the WAQF. In some cases when the number of beneficiaries is a handful, there is no need for an administrator (Hasan, 2017). The relatives act as per the set guidelines created by the founder.

\subsection{Termination}

Although WAQF is expected to operate in perpetuity and last forever, there are conditions under which the Waqf can be terminated:

- If the associated goods are damaged. In this case, goods become invalid and cannot be used as outlined by the founder. The remains are diverted to the founder or remaining heirs.

- Waqf can be terminated by the $k \bar{a} d \bar{l}$ if the formation involved the violation of Islamic laws.

- According to the Maliki school of thought, termination can be outlined in the founding contract. This includes termination once the objectives of the Waqf are achieved. In this case, the property is returned to the founder or the heirs or whoever is outlined in the founder's will.

\section{Legal Framework of WAQF}

The legal framework that guides WAQF has been informed by the advances and guidelines set over centuries. According to the trust, the founder has the right to designate a property for use by beneficiaries in perpetuity, and after the contract, the property changes to WAQF. This means that the owner/founder permanently ceases to control it. In this case, ownership is detained, and the founder ceases to have control whatsoever. Property cannot be shifted by him or her or by the administrator or beneficiaries. There is some sense of "arrest" of property, which means that it is safeguarded from seizure or sale (Rashid, 2018). Ultimately, all WAQF are surrendered to charity, but this should not be immediate. The founder sets a specific condition. While WAQF AHLI aims to help the vulnerable, finding those utilized to help the founder's descendants and, upon extermination, devolves to charity. Within the legal framework, there is a chance to challenge WAQF based on abuse or illusion 
or other people's right or in the case where the set dedication demoralizes the rights of the creditors or compromises an individual's right. All jurist agrees that the fundamental parts of a valid Waqf include the founder, declaration, beneficiary, and property. According to Sait and Lim (2006), the essential component includes a waqif of mature and sound mind, qurbah (religious purpose) and ghah (a declaration), WAQF fi-sabilillah (endowment in the way of Allah) to set up an endowment, mawquf' alayh (a beneficiary or beneficiaries) and property to act as a WAQF.

Legally, the WAQF should be authenticated and stored with a qadi. This means that the WAQF is more important than the legal framework, and in some situations, the Waqf properties have engravings of curse on those who can alter the founders' conditions. Because of the prevailing Islamic views and perception of the founders' conditions, disputes are limited. These laws that guide all activities related to WAQF form an essential part of Sharia law. There is a close association between Waqf and other facets like inheritance, gifts, and marriage, and it is sometimes included as part of family law.

In any WAQF, with whatever pious motive, there must be compulsory inheritance rules. Moreover, since WAQF is indivisible, founders who wish to avoid the division of property for inheritance are an opportunity for founders. From inception, people from different backgrounds have bequeathed different property types to varied beneficiaries, charitable and for causes ranging from deeply religious beliefs to show generosity to narrow and selfish wish of disinheriting females (Abbasi, 2012). In general, there are two types of WAQF, namely the public and private or family. First, the WAQF KHAIRI element involves a permanent devotion of wealth to a charitable cause such as building and managing madrassa. When established during WAQIF, these endowments start immediately and may involve part of or all of the WAFIQ'S property (Karim, 2010). If the intention is to take effect after the founder is dead, there is a possibility of revocation or change at any stage before death.

Nevertheless, such WAQF is subjected to limits in Muslims' wills because the endowment may not surpass one-third of the total asset. There is another form of WAQF which misleads many people in the legal context. This is the private or family endowment. In this context, property and the subsequent income are kept for the family or specified individual until the death of the final founder's descendants; after that, the remaining is redirected to charitable organizations. It is the best option of securing the family wealth from uncertain disturbances that may arise from economic and political uncertainties. In this situation, a property is permanently endowed and cannot be seized by any whim of power. There is protection for families or competitors against property grabbing. In the Arab nations, this type of endowment is called waqf Ahli or WAQF DHURRI and WAQF AL AULAD in South Asia.

For WAQF AL AULAD, which was used in South Asia, the land was controlled by a single male heir, mostly the first son, with an allowance given to other family members. In some cases, a third-party category was included (WAQF MUSHTARAK), also described as a quasi-public endowment to cater for specific 
people or class of individuals and other outside interested groups such as mosque convenient for, but not limited to close relatives (Bakar, 2018). WAQF GAYRI SAHIH is another type of Waqf created by the state because it was created from the state treasury or created to be administered by the state. Besides these differences, the principles remain the same, with slight differences in jurisdiction between Sunni (Sunni Maliki, Sunni Hanafi, Sunni Shafi'i, and Sunni Hanbali) (Abbasi, 2012). According to Sunni Shafi's school, specific words should be applied to show purpose to create a WAQF, and the benefactors must obey its terms. This is different from other schools (Bakar et al., 2017).

The prevailing socio-economic, legal, and political situations have led to changes in the legal framework around WAQF. Now, rules can vary based on the geographical area and the dominant jurisprudential school. Different approaches depend on whether the jurisdiction applied shifts towards Egypt, Central Asia, or part of the Persian Gulf area. On the issue of ownership, jurists have divided opinions. While, in theory, WAQF should be dedicated to Allah, it temporarily raises concerns of ownership. It signified that the "arrest" of property is made so that proprietary rights cannot be executed over the property itself but rather over income. The following Table 1 outlines the major types of WAQF and their respective purposes.

Table 1. Major types of WAQFs and their Purposes

\begin{tabular}{|l|l|}
\hline WAQFS & Aim/Purpose \\
\hline $\begin{array}{l}\text { WAQF } \\
\text { AHLI/DHURRI }\end{array}$ & $\begin{array}{l}\text { A private or family endowment to help the } \\
\text { vulnerable, and to be redirected to charitable } \\
\text { organizations upon the founders' final descendant. } \\
\text { WAQF KHAIRI } \\
\text { Permanent devotion of wealth to a charitable cause, } \\
\text { in the form of buildings, e.t.c. }\end{array}$ \\
\hline WAQF GAYRI & $\begin{array}{l}\text { Created from the state treasury or created to be } \\
\text { administered by the state. }\end{array}$ \\
\hline $\begin{array}{l}\text { WAQF } \\
\text { MUSHTARAK }\end{array}$ & $\begin{array}{l}\text { A quasi-public endowment, catering for specific } \\
\text { people or class of individuals but not limited to close } \\
\text { relatives. }\end{array}$ \\
\hline $\begin{array}{l}\text { WAQF AL } \\
\text { AULAD }\end{array}$ & $\begin{array}{l}\text { Private or family endowment specific to South Asia, } \\
\text { controlled by a single male heir. }\end{array}$ \\
\hline
\end{tabular}

Source: Own creation.

\section{Property and the Cash WAQF}

In most cases, WAQF is a property that promotes the act of continuous charity. There are movable assets like animals or furniture that can be considered in WAQF, and the jurist classifies the movable assets as a practice from the prophet's time. Since perpetuity of the trust is a standard rule, money had not often been considered a valid subject matter (Yussof and Al-Harthy, 2018). During the Ottoman period, a particular type of endowment or trust fund was used. At this time, money was allocated explicitly for social and pious reasons. The actual nature of WAQF, which meant "arrest," is that a property is entirely tied up and endowed to a charitable purpose. There are no proprietary rights at any time on the endowment but only on the revenue 
acquired from it, and this must be settled in perpetuity. The use of cash in WAQF has presented some challenges within Islamic law since it does not maintain long-term attributes like real estate. The sustainability of cash is therefore interrogated when used.

After continuous deliberation on the matter, the Ottoman jurist concluded and validated the use of cash. Movable assets were approved based on WAQF; cash was accepted as a moveable asset, which meant cash endowment approval. Nevertheless, this was not conclusive as some jurists continued to argue on the validity of cash as an endowment through the 16th century. The study of court registers shows that cash endowment during the 15th and 16th centuries survived. This means that cash endowment was perpetual in WAQF involving real estate (Hassan et al., 2018). Since now endowed capital can be topped up year after year in cash or other forms, through revenue it generates and other contributions, there is some explanation to the resilience of its use. Cash endowment played a critical role as a credit source, and the returns were reinvested into charity projects after any deductions and taxes. Money acquired from credits that were not distributed as per the WAQF provider's conditions was added to the endowment capital.

Questions have been raised on whether cash WAQF contravened the Sharia law on interest. While some historians argued that the cash interest violated the Muslim laws that guided finance and banking, others have stated that this was an "interest-like" payment. They argue that this was a share of the profit hence within the legal framework of Muslim laws (Salarzehi et al., 2010).

\section{Perception of Cryptocurrency in Islam}

Islam as a religion is steadily growing globally, with more than 1.6 billion Muslims in the world (Lipka, 2017). When it comes to banking and finance, Muslims have unique needs guided by the Islamic Canonical Law, also known as Sharia. These policies and guidelines in the banking sector are in line with the teachings of the Quran and prohibit some activities like acceptance of interest which is considered Riba, or investment in other businesses which contravenes the Islamic belief, such as the sale of alcohol. Recently, there has been an increased interest in Islamic banking worldwide, with international bodies like the International Monetary Fund (IMF) discussing Islamic banking. The increasing use of Blockchain has reached the Islamic world, and most Arabic nations are slowly embracing this technology (Vizcaino, 2018). The UAE has introduced BitOasis, an exchange platform that offers services such as Bitcoin Wallet. These services have stretched to Qatar, Kuwait, and Saudi Arabia (Shares, 2016). While these services continue to dominate other Islamic nations, numerous questions have arisen whether Blockchain is Halal basing on the fact that Islam ethical standards control the Islamic banking and financial sector.

Blockchain can be utilized as a currency and a payment system, and this distinction is critical because the Sharia laws that apply vary. When dissecting how Sharia perceives monetary transactions, it is essential to bring in the concept of Gharar 
(uncertainty). Gharar is forbidden since it operates against the idea of certainty and openness in business transactions. This can arise when the claim of ownership in a business transaction is suspicious (Crosby et al., 2016). While Blockchain currencies were earlier volatile and unpredictable, there has been some sense of stability over the last few years. This rules out the concept of Gharar. The debates for and against Blockchain in the Islamic banking system have triggered cryptocurrency companies to launch instruments based on physical assets authorized by valid Islamic jurists (Sait and Lim, 2006). At OneGram cryptocurrency, a unit is supported by at least one physical gold in a vault which is aimed at limiting speculations (Vizcaino, 2018). Gold is one of the ancient forms of money in the Islamic System, and this validates the fact that Blockchain is permissible and can be used in the Islamic banking and finance sector. The reason for bringing the concept of gold is to prove Sharia's rules and regulations on the use of digital Blockchain technology. In Malaysia, another Blockchain company known as HelloGold created a gold-backed cryptocurrency offer after getting an endorsement from Islamic scholars. The presented information proves that Islam accepts intrinsic commodities that can be used as money, both electronic and paper, if intrinsic commodities support it. This means that the use of Blockchain is permissible under Islamic law.

\section{Use of Blockchain in Islamic Banking and Finance}

The introduction of Blockchain in Islamic banking and Finance holds excellent prospects for investors in the Waqf banking sector and stakeholders.

\subsection{Smart Contracts}

There is the leverage set by Islamic finance on different contracts like profit sharing, alliances, and agency platforms to prevent interest and speculations. An average financing partnership, for instance, requires at least three contracts from multiple parties. For the case of a conventional loan agreement, there is a need for the borrower and the banking institution only. As a result, the need for additional contracts in Islamic finance is equivalent to increased administrative and legal deliberations, leading to higher fees on the end-user. Through smart contracts, there is a clear line on how Blockchain operates. Smart contracts are digital contracts, and the terms are coded electronically to operate only when the conditions are met. This triggers the contractual process in the Islamic financial institution and alleviates subsequent administrative complexities (Habib and Ahmad, 2020). Additionally, smart contracts can be easily verified and are irreversible. Because of this, the possible operational risks from the settlement are mitigated. These features prove that smart contracts can streamline operations within the Islamic banking and finance sector.

\subsection{Distributed Cloud Storage}

Most cloud storage services are linked to central servers. This runs the risk of compromising data in context from one point of entry. Users, therefore, need to establish trust with a single provider. With a decentralized system, the risks of 
conflicts between participants are eliminated. For a decentralized network, an individual needs to trust static protocol in Blockchain controlled by cryptographic algorithms. The ordinary laws around mathematics are absolute and hence credible.

Cloud storage can help manage the massive amount of data and information that comes from Islamic institutions. Decentralized data storage creates two advantages. There are user security and cost-efficiency. Now, data storage is stored in a central server. This is inefficient and creates a risk of cyber-attacks and possible data manipulation or loss. The distributed storage, therefore, eliminates the need for documentation.

\subsection{Digital Currencies}

The invention of Blockchain correlates with the arrival of cryptocurrencies, significantly, bitcoin. This means that it is only fair to assess individuality's elements to understand their compatibility with Islamic finance. Other than fiat money, Blockchain cannot be created from thin air. A significant amount of effort and resources are needed to produce an adequate Blockchain supply like bitcoin (Mohsin et al., 2016). The process is known as "mining" where people use complex computer systems and software to solve complicated mathematical problems using cryptography. The process leads to the security of the entire network and the development of Blockchain as a reward to the miners.

Since Blockchain has a decentralized network, miners help secure the transactions. The miner's interest is naturally aligned because they are rewarded with cryptocurrencies for successful block secured. The time taken by miners and computer power represents the value that authorizes the formation of cryptocurrencies. This differs from the fiat system, where banking institutions and government agencies create money from a consistent value injection (Hasan et al., 2020). The fiat system is debt-based and follows that if a bank makes a loan, a simultaneous match is deposited in the borrower's bank account, which generates new money. In the Islamic system, money should have an intrinsic value, and this should resonate with Waqf.

\section{The Use of Blockchain in WAQF}

During the Ottoman Era, the creation of WAQF helped develop outstanding benefits in enriching the welfare of the vulnerable throughout their lifetime. Moreover, buildings and lands were given to help in education, medical services, and other essential services through the system. As a result, the Ottoman Empire managed to reduce poverty for years significantly. To a large extent, WAQF helped improve the lives of the vulnerable and orphans, but this has slightly changed in the contemporary world. There are challenges with liquidity, transparency, and WAQF management, which has affected how the trust is controlled towards achieving the bigger picture of improving life. For years, jurists have debated and engaged on how to control the issue without success. Until February 2019, when Fonterra, a technology 
organization, managed to launch the WAQF chain, focusing on how Blockchain could be included in WAQF. In the project, Fonterra proposed a platform that could solve liquidity issues; by using Blockchain to raise funds for the development of projects aimed at helping the orphans and the vulnerable (Mohsin, 2019). Blockchain has provided some hope to rejuvenate the glory days of Waqf. Donations through cash sorted the issue of unproductivity and immobilized properties since money given for Waqf provided long-term benefits to the community (ummah).

Contrary to other forms of donations, there is a high degree of transparency in the use of Blockchain. All transactions are recorded publicly, and authorized personnel can view transactions. Users using the WAQF chain can also track their transactions from the point of gift to the point it is used by the beneficiaries. There is also a "smart contract" feature that enhances the performance and efficiency within the WAQF institutions while at the same time focusing on security and adherence to WAQF conditions. It is important to note that the relationship between WAQF and Blockchain is mutual. While information awareness is a significant challenge for Blockchain's use, there has been an increasing interest in the financial and banking sectors. This new technology aims at using Blockchain to manage investments in WAQF. As a result, a massive pool of assets across the Muslim world will be captured (Laallam et al., 2020). It is more efficient in raising donations to facilitate school constructions, mosques, and other welfare schemes. Fonterra plans were triggered by the increasing number of banking and financial institutions setting foot in Islamic banking systems.

Bitcoin can be used in WAQF as a tool for collecting funds across the globe in an efficient and timely manner. Simultaneously, it eases information collection within the system by improving the elements of trust and reliability of activities undertaken. Through Bitcoin, the project stakeholders can monitor transactions to enhance the level of trustworthiness and reliability. There is also a sense of security that comes with the use of Bitcoin in the collection and management of funds (Abbasi, 2012). In the globalized system, government operates and functions as the organizer and regulator and helps manage the WAQF operations. Enhanced engagement of government in promoting WAQF shows that there is low-risk management. In other words, the government has considered the trust as a fraction of the economy, and as a result, there is an increased effort to participate in projects that boost the economy. While still on the role of government in promoting WAQF, there is the downside of it. There is more strict bureaucracy in adherence. However, this belief can be proven wrong when applicants adhere to routine procedures, for instance, Blockchain technology.

\subsection{Issues of the WAQF Chain to Solve}

\subsubsection{Enhance Transactional Transparency}

In some regions, transactions dealing with property have been risky. Records that exist are paper documents filed manually with administrators who cannot keep the archives straight. In this context, the use of Blockchain will help keep transactional 
records and help manage the WAQF as per the founder's rules. At the same time, the level of transparency eliminates the possibility of shortchanging relatives and vulnerable beneficiaries.

\subsubsection{Eradication of Corruption}

The technology is designed to facilitate borderless digital currently and is free from the control of financial institutions and agencies that might intent to shortchange beneficiaries in a WAQF. Besides, it stores records in electronic codes and links in a chained structure, making it difficult to manipulate (Salarzehi et al., 2010). The exiting verification mechanism creates trust where trust does not exist. For instance, a ledger is copied among different nodes and eliminates the possibility of falsifying records.

\subsubsection{Crowdfunding for Development}

Crowdfunding takes on the idea of crowd-based decision making and applies to fund projects. In this case, small contributions are collected to form significant capital to facilitate a project. This is done through online platforms. There are different types of crowdfunding with varied legal complexities. There is donation-based crowdfunding which focuses on donations to charitable initiatives and to support a social cause. Islamic law about finance and crowdfunding demands fair distribution of benefits and obligations between the concerned parties when undertaking financial transactions (Abbasi, 2012). Through the WAQF chain, the element of fair distribution and obligation will be achieved.

\subsubsection{Integrated Property Development Ecosystem}

The WAQF chain creates a model that eliminates development issues and integrates all operations into a single roof. Through its unique concept, the WAQF chain helps monitor and manage estate endowments' establishment and development. All organizations involved are engaged to facilitate reaching a holistic and contextual development decision. This brings long-term operational sustainability to projects. It is sharia-compliant and brings founders and donors together to engage in social projects that enhance financial inclusion or the welfare of the society at large.

\section{Obstacles and Challenges of Using Blockchain in WAQF}

Some several challenges and obstacles affect the use of Blockchain for WAQF. These issues revolve around technical, market, legal, and awareness challenges. Some of the most predominant challenges include scalability and current regulation, which vary across different countries. Moreover, since there has been a need to improve the collection of WAQF across different nations in Blockchain, the element of legality has affected its success. It is fundamental for the stakeholders to understand the general tradeoffs and make sound choices that involve database and Blockchain.

First, there is a need to outline the strengths and weaknesses of technology (Yussof and Al-Harthy, 2018). Identifying the right balance is good in marrying the acquired benefits with back-end information or the general applications as part of the initiative 
to increase awareness. Besides the legal issue, there is the aspect of keeping Blockchain data for historical and analytical purposes.

There has been government interference that has affected the utilization of Blockchain both in the Islamic system and as a form of funding the WAQF. Some central banks and governments issued warnings against the use of Blockchain. Until now, there is no holistic regulation on the use of Blockchain across the Islamic nations, and this is expected to continue until policymakers, and opinion leaders feel comfortable using it (Bakar, 2018). This has affected the awareness of the technology as governments send misleading signals. These actions further risk short circulating the leadership of Blockchain technology and organizations that seek to promote it. It is evident that government regulation is expected to assure customer safety and introduce standardization levels, but total obstruction will not help. Compliance should be an essential agenda for the stakeholders pushing the use of Blockchain in WAQF.

When using Blockchain to pay WAQF, there is compliance and non-compliance, which affects profit margins. Avenues, where compliance with this system can lead to resolutions include using Blockchain tokes as actual value, acknowledging the transactions undertaken through Blockchain, and allowing legal links to intelligent contracts (Mohsin et al., 2016). Every Blockchain requires a personalized technology infrastructure, an active ecosystem around it, and partners to support it. From the technology perspective, a protocol is a minor requirement, and while it requires to be amplified by software, it is the network of players that surrounds it that affects the Blockchain's market success. In case there is no adoption, little impact is felt. Another challenge linked to the use of Blockchain is the lack of "killer Apps" to increase usage among founders and beneficiaries in the context of WAQF and other areas. Lack of understanding of the essential competencies of Blockchain in facilitating the collection of WAQF deters executives from understanding its full potential. This can be solved when there is a concerted effort to create awareness on Blockchain and its potential to the Muslim community and prospective WAQF founders worldwide (Hasan, 2017). Unless adequate awareness is done, there will be continuous confusion and uncertainty within the Blockchain space.

Regulation is another obstacle that affects the use of Blockchain in WAQF. This is because it is a blockbuster and touches almost all sectors of the economy. As a result, different economic departments bring diverse flavors of regulation. A fundamental paradigm shift that stakeholders will need to understand is that there are changes, and Blockchain moves away from the central control (Hassan et al., 2018). Since the nature of trust is transforming and regulators are used to policies that approach the financial sector from a central point, they will need to adjust when dealing with Blockchain or any other intermediary that does not conform to their model centralized regulation. Originally, Blockchain is decentralized, and this creates difficulty in regulation. This will call for innovative ideas to regulate it. The following Table 2 summarizes the uses of Blockchain in WAQF as well as Islamic banking and finance and the challenges that come with the use of Blockchain. 
Table 2. Uses of Blockchain in WAQF and Islamic finance, and Major challenges facing the utilization of Blockchain.

\begin{tabular}{|c|c|}
\hline Use of Blockchain in Islamic Banking \& Finance & Use of Blockchain in WAQF \\
\hline $\begin{array}{l}\text { Smart contracts streamline operations within the } \\
\text { Islamic banking and finance sector, reducing legal fees }\end{array}$ & $\begin{array}{l}\text { Enhances transaction transparency and help } \\
\text { keep transaction records intact }\end{array}$ \\
\hline $\begin{array}{l}\text { Decentralized data storage provides user security and } \\
\text { cost-efficiency }\end{array}$ & Eradication of corruption \\
\hline $\begin{array}{l}\text { The mining of digital currencies helps secure } \\
\text { Blockchain transactions }\end{array}$ & Facilitates Crowdfunding for development \\
\hline & $\begin{array}{l}\text { Provides an integrated } \\
\text { development ecosystem. }\end{array}$ \\
\hline \multicolumn{2}{|c|}{ Obstacles and Challenges of using Blockchain in WAQF } \\
\hline \multicolumn{2}{|c|}{ Scalability } \\
\hline \multicolumn{2}{|c|}{ Variation of modern regulations and legality across different countries due to decentralization } \\
\hline \multicolumn{2}{|c|}{ Government interference } \\
\hline \multicolumn{2}{|c|}{ Lack of awareness of Blockchain technology } \\
\hline \multicolumn{2}{|c|}{ Lack of understanding of the basic competencies of Blockchain in facilitating Waqf collection } \\
\hline \multicolumn{2}{|c|}{ Issues of compliance and non-compliance } \\
\hline
\end{tabular}

Source: Own creation.

\section{Conclusion}

Blockchain, as new technology, has gained significant dominance across the globe. It has created a system that facilitates business management and control of transactions with limited intermediaries. The limited intermediaries promote it as the safest mode of payment, eliminating possible corruption and cost-efficient compared to traditional technologies. These benefits have ushered the use of Blockchain in the Islamic system and particularly funding WAQF, which is established for social welfare and promoting the wellbeing of the vulnerable in the society.

Before considering Blockchain in the Islamic system, we need to assess if it is a Halal (permissible) and evaluate issues of the technology's volatility and the fact that most governments are yet to embrace it. When dissecting how Sharia perceived money, it is essential to bring in the concept of Gharar (uncertainty). Gharar is forbidden since it operates against the idea of certainty and openness in business transactions. This can arise when the claim of ownership in a business transaction is suspicious. While Blockchain currencies were earlier volatile and unpredictable, there has been some sense of stability over the last few years.

For a WAQF to be valid, some components must exist. These include the founder, funding declaration, the estate, beneficiaries, relatives or public charity projects, and administrators who ensure the WAQF rules are achieved. In some cases, WAQF can outline the conditions for termination. From the legal perspective, a person has the right to set aside a property to use by beneficiaries in perpetuity, and the property changes to WAQF upon the declaration by the owner, permanently preserving the income for a specific resolution. Ownership must be detained after a property is surrendered and the founder ceases to be the owner. Because of the possible complexities in tracking property and financial proceeds given by a founder, 
Blockchain emerges to be the best option to manage WAQF. It helps eradicates possible corruption, improves transactional transparency, and acts as an integrated property management system where all stakeholders can engage and make a contextual decision. Possible challenges that can affect the implementation of the technology include scalability, cross-border regulations, and awareness. There is a need for stakeholders to engage and sensitize founders that using Blockchain technology is promoting WAQF.

\section{References:}

Abbasi, M.Z. 2012. The classical Islamic law of WAQF: A concise introduction. Arab Law Quarterly, 26(2), 121-153.

Abojeib, M., Habib, F. 2019. Blockchain for Islamic social responsibility institutions. In Fintech as a Disruptive Technology for Financial Institutions, 221-240. IGI Global.

Alidin, A.A., Ali-Wosabi, A.A.A., Yusoff, Z. 2018. Overview of blockchain implementation on Islamic finance: Saadiqin experience. In: 2018 Cyber Resilience Conference (CRC), 1-2, IEEE.

Al-Razouki, D. 2018. Crypto-WAQF: Building a Sustainable Islamic Blockchain. Retrieved from: https://medium.com/@Mussaad/crypto-waqf-building-a-sustainableislamic-blockchain-6adb2fab9f1f.

Alzubaidi, I.B., Abdullah, A. 2017. Developing a digital currency from an Islamic perspective: case of blockchain technology. International Business Research, 10(11), 79-87.

Bakar, M.A. 2018. Concept of Revenue, Expenses and Liabilities in Accounting for Zakat, WAQF and Baitulmal in Malaysia: An Analysis from Shariah Perspective. International Journal of Zakat, 3(4), 1-16.

Bakar, N.A., Rosbi, S., Uzaki, K. 2017. Cryptocurrency framework diagnostics from Islamic finance perspective: a new insight of Bitcoin system transaction. International Journal of Management Science and Business Administration, 4(1), 19-28.

Crosby, M., Pattanayak, P., Verma, S., Kalyanaraman, V. 2016. Blockchain technology: Beyond bitcoin. Applied Innovation, 2(6-10), 71.

Elasrag, H. 2011. Blockchains for Islamic finance: obstacles \& challenges.

Habib, F., Ahmad, A.U.F. 2020. Using Blockchain and Smart Contracts for WAQF Institutions. In: Financial Technology and Disruptive Innovation in ASEAN, 225-244. IGI Global.

Hasan, R., Hassan, M.K., Aliyu, S. 2020. Fintech and Islamic Finance: Literature Review and Research Agenda. International Journal of Islamic Economics and Finance (IJIEF), 3(1), 75-94.

Hasan, R., Siraj, S.A., Mohamad, M.H.S. 2017. Antecedents and Outcome of WAQF's Trust in WAQF Institution. Journal of Economic Cooperation \& Development, 38(4), 155-179.

Hassan, N., Abdul-Rahman, A., Yazid, Z. 201. Developing a new framework of WAQF management. International Journal of Academic Research in Business and Social Sciences, 8(2), 287-305.

Karim, S.B.A. 2010. Contemporary Sharia's compliance structuring for the development and management of waqf assets in Singapore. Kyoto Bulletin of Islamic Area Studies, 3(2), 143-164. 
Laallam, A., Kassim, S., Adawiah, ER., Saiti, B. 2020. Towards knowledge based WAQF organizations. In Challenges and Impacts of Religious Endowments on Global Economics and Finance, 100-120, IGI Global.

Lipka, M. 2017. Muslims and Islam: Key findings in the US and around the world. Pew Research Center, 9.

Mohamed, H., Ali, H. 2018. Blockchain, Fintech and Islamic Finance. De. G Press, Walter de Gruyter Inc., Boston/Berlin. DOI, 10, 9781547400966-202.

Mohsin, M.I.A. 2019. WAQFinTECH and Sustainable Socio-Economic Development. International Journal of Management and Applied Research, 6(3), 130-141.

Mohsin, M.I.A. et al. 2016. Legal framework of the institution of WAQF. In Financing the Development of Old WAQF Properties, 1-2, Palgrave Macmillan, New York.

Noja, G.G., Thalassinos, E., Cristea, M., Grecu, I.M. 2021. The Interplay between Board Characteristics, Financial Performance, and Risk Management Disclosure in the Financial Services Sector: New Empirical Evidence from Europe. J. Risk Financial Management, 14, 79. https://doi.org/10.3390/jrfm14020079.

Pilkington, M. 2016. Blockchain technology: principles and applications. In Research handbook on digital transformations. Edward Elgar Publishing.

Rabbani, M.R., Khan, S., Thalassinos, E.I. 2020. FinTech, blockchain and Islamic finance: an extensive literature review. International Journal of Economics and Business Administration, 8(2), 65-86. DOI: 10.35808/ijeba/444.

Rashid, S.K. 2018. Potential of WAQF in contemporary world.

Sait, S., Lim, H. 2006. Land, law, and Islam: property and human rights in the Muslim world, 1, Zed books.

Salarzehi, H., Armesh, H., Nikbin, D. 2010. WAQF as a social entrepreneurship model in Islam. International Journal of Business and Management, 5(7), 179.

Shares, D. 2016. Dubai startup BitOasis announces its first round of funding. Bitcoin News. Retrieved from: https://news.bitcoin.com/dubai-startup-bitoasis-announces-firstround-funding/.

Swan, M. 2015. Blockchain: Blueprint for a new economy. O'Reilly Media, Inc.

Vizcaino, B. 2018. Onegram Lists Islamic Cryptocurrency on its Own Virtual Exchange. Retrieved from: https://www.reuters.com/article/islamic-financecryptocurrencies/onegram-lists-islamic-cryptocurrency-on-its-own-virtualexchange-idUSL8N1W41X9.

Yussof, S.A., Al-Harthy, A. 2018. Cryptocurrency as an Alternative Currency in Malaysia: Issues and Challenges. Islam and Civilizational Renewal, 274(6071), 1-18.

Zheng, Z., Xie, S., Dai, H.N., Chen, X., Wang, H. 2018. Blockchain challenges and opportunities: A survey. International Journal of Web and Grid Services, 14(4), 352-375. 